内部空間との関係にみる近代住宅の外部空間の構成に関する研究

南カリフォルニアにおける R.M.シンドラーとR.J.ノイトラの住宅の比較を通して

\title{
A RESEARCH ON THE COMPOSITION OF OUTDOOR SPACES BY ANALYZING THE RELATION TO INDOOR SPACES IN MODERN HOUSES \\ Comparison of works by R.M. Schindler and R.J. Neutra in Southern California
}

\author{
那須 聖*, 村田 涼**, 八木幸二*** \\ Satoshi NASU, Ryo MURATA and Koji YAGI
}

\begin{abstract}
This study is intended to clarify the relation between house and site by analyzing the composition of outdoor spaces of modern California houses. The characteristics of outdoor spaces are defined by relation to indoor spaces. The way of composing site and house is analyzed in relations to streets, comparing the characteristics of outdoor spaces. As the result of classification, 6 types of circulation schemes and 9 types of compositional schemes of outdoor spaces are identified in the houses of Schindler and Neutra. Typical circulation schemes are the type in which personal and common spaces are separated in indoor space as well as in outdoor space. And typical compositional schemes share a back-outdoor-living space protecting personal indoor and outdoor spaces.
\end{abstract}

Keywords: Composition of Outdoor Spaces, Site, Relation to Indoor Spaces, Common, Personal, Modern California Houses

外部空間の構成, 敷地, 内部空間との関係, 共用, 個人用, カリフォルニアの近代住宅

\section{1. 研究の目的}

住宅と敷地, 周辺環境の関係は, 一住宅の居住空間をいかに形成 するかという問題にとどまらず，住宅の集合としての町並みの形成 にかかわる問題であるといえよう。本研究は近代建築の表面上の意 匠や形式を問うものではなく，建築家による住宅と敷地，周辺環境 に対する姿勢を図式化し，建物や部位の構成にとどまらない広い視 点から住宅を理解するものである.

著者らはこれまで，南カリフォルニアの住宅を対象として，その 様式的特徴ではなく，周辺環境としての敷地や外部空間と建物の関 倸を問題として研究 (12)314)5) 6) を行ってきた。 それらは，ある地域の 住宅を歴史的な装飾や様式によって捉えるのではなく，時代性から 独立し，特定の地域の環境に対応した住宅がいかにあるべきかとい う問題をあつかったものである。

ケース・スタディー・ハウスにおける住宅の構成と建築家の言説

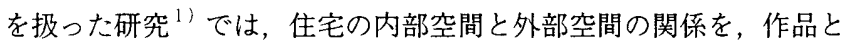
言説の分析から考察し，設計者による意図と作品の空間構成の差異 を明らかにすることによって, 周辺環境に対する建築家の姿勢を解 明した。シンドラーの住宅を対象とした平面構成と素材・架構の表 現に関する研究 ${ }^{2}$ では，住宅の内外空間の関係，内部空間相互の関 係に基づく概念軸を提示し, それらの軸と素材や架構による空間表
現がいかに関係しているかを分析し，立体的なヴォイドがなす形態 構成にとどまらない空間の構成法を考察した．内外空間の配置・配 列構成による建物と敷地の関係に関する研究 ${ }^{3)}$ では, 前 2 稿の内 外空間の関係に関する研究を進め, 前面道路と敷地の関係を考慮し た内外の関倸を記述し，公私の関係を対比的に捉える敷地の基本的 図式を明らかにしている。

本研究は, 前稿の内外空間の配置・配列構成による研究 ${ }^{3)}$ をふま え，そこではふれなかった内部における機能空間の動線的関係と， 内部空間との関係による外部空間の性格を問題とし，個々の外部空 間の共用, 個人用の関係と敷地に占める位置から敷地の構成を類型 化し，建築家の敷地に対する理解を図式化するものである，対象と する住宅は前稿に引き続きR. M. シンドラー ${ }^{7)}$ とR.J.ノイトラ ${ }^{8)}$ の住 宅作品とする。

前稿までに述べたように，シンドラー，ノイトラに関する既往の 研究は，建築家の経歴や作品を紹介したなもの $\left.{ }^{9)}-18\right)$ から，個々の 作品分析 $\left.{ }^{19}\right)^{20)}$ まで多数である。近年，日本においても研究が進ん でおり，それらは，両者を個別に空間構成について分析したものい! -25)が多い。

発想の類似性がみられるものとしては，住宅と前面道路との関係 を扱ったもの 26 があるが，内部空間に関する分析にとどまっている.
* 東京工業大学:工学部建築学科 助手.工修

** エステック計画研究所「修

*** 東京工業大学迆学部建築学科教授・ 工.博
Assoc., Dept. of Architecture, Faculty of Engineering, Tokyo Institute of Technology, M. Eng.

Estec, M. Eng.

Prof., Dept. of Architecture, Faculty of Engineering, Tokyo Institute of Technology, Dr. Eng. 
外部と内部の配置構成を問題としたもの ${ }^{27)}$ では，外部空間の形態と 用途を建物ヴォリュームとの関係によって記述しているが，面積配 分などによる敷地全体の形態・構成の記述に焦点が絞られている.

以上をふまえると，本研究の独自性は，特定の地域の複数の建築 家による住宅を扱うことによる近代住宅の地域的理解，内部空間と の関係による外部空間の性格の定義, 複数の性格を持った個々の外 部空間による敷地の構成の記述；前面道路を基準とした共用と個人 用の関係の図式化という点にある.

\section{2. 研究の方法と論文の構成}

敷地内に扔いて住宅を形成する空間は，建物内の機能空間に限ら ず，外部の居住空間，テラス，バックヤード，駐車スペース，景観 としての庭など複数の外部空間があり，それらの総体として一つの 住宅が成立している．特に，屋外の居住空間は温暖な南カリフォル ニアの気候を反映したものであり，シンドラーとノイトラは雑誌の 記事や著作 ${ }^{28)}$ でその有用性について述べていることからも，両者の 住宅作品では居住空間として重要な位置を占めていると言える。こ れら住宅における内外の居住空間は，敷地内とその外部の周辺環境 との差異化によって成立していることを前提とするならば, 前面道 路，隣地，眺望といった様々な条件によって意味が異なるであろう。 本研究において着目する住宅と主要なアプローチのある前面道路と の位置関倸によっても意味は異なり，建築家はこれらの差異により 個々の空間を敷地全体へ当てはめて構成していると考えることがで きる。

ここで個々の空間とは，内部においては壁や建具によっで分節さ れたリビングルームやベッドルーム，キッチンといった機能空間で

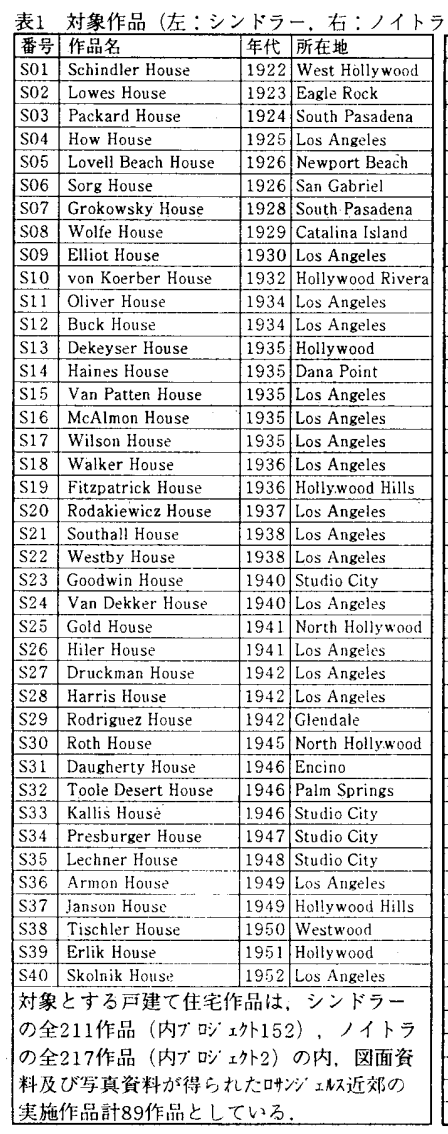

\begin{tabular}{|c|c|c|c|}
\hline 番号 & 作品名 & 年代 & |所在地 \\
\hline No1 & Lovell Health House & 1929 & $\begin{array}{l}\text { Los Angeles } \\
\end{array}$ \\
\hline $\mathrm{N} 02$ & Beard House & 1934 & Altadena \\
\hline N03 & Stenberg House & 1935 & Northridge \\
\hline No4 & Plywood M. House & 1936 & Westwood \\
\hline N05 & Miller House & 1937 & Palm Spring \\
\hline N06 & Gill House & 1939 & Glendale \\
\hline N07 & Berger House & 1939 & Norh Hollywood \\
\hline N08 & McIntosh House & 1939 & Los Angeles \\
\hline N09 & Becksstrand House & 1940 & Palos Verdes \\
\hline N10 & $\begin{array}{l}\text { Nesbitt House } \\
\end{array}$ & 1942 & Los Angeles \\
\hline N11 & Kaufinann D. House & 1946 & Palm Spring \\
\hline N12 & Bailey C. S. Honse & 1946 & Los Angeles \\
\hline N13 & Tremaine House & 1948 & Montecito \\
\hline N14 & Reunion House & 1949 & Palos Verdes \\
\hline N15 & Hinds House & 1951 & Los Angeles \\
\hline N16 & \begin{tabular}{|l|} 
Logar House \\
\end{tabular} & 1951 & Granada Hills \\
\hline N17. & McElwain House & 1952 & $\begin{array}{l}\text { Reseda: } \\
\end{array}$ \\
\hline N18 & Moore House & 1952 & Ojai \\
\hline N19 & $\begin{array}{l}\text { Hall House } \\
\end{array}$ & 1953 & Newport Beach \\
\hline $\mathrm{N} 20$ & Kesler Houlse & 1953 & $\begin{array}{l}\text { Los Angeles } \\
\end{array}$ \\
\hline N21 & Kraner House & 1953 & Norco \\
\hline $\mathrm{N} 22$ & Scharnan House & 1953 & Los Angeles \\
\hline $\mathrm{N} 23$ & Hammerman House & 1954 & Los Angeles \\
\hline $\mathrm{N} 24$ & Weston House & 1954 & Los Angeles \\
\hline N25 & \begin{tabular}{|l} 
Brown House \\
\end{tabular} & 1955 & \begin{tabular}{|l} 
Los Angeles \\
\end{tabular} \\
\hline N26 & \begin{tabular}{|l} 
Hansch House \\
\end{tabular} & $\frac{2955}{1950}$ & Clarenont \\
\hline N27 & Perkins House & 1955 & $\begin{array}{l}\text { Pasadená } \\
\end{array}$ \\
\hline N28 & Roberts House & 1950 & Covina \\
\hline N29 & Staller House & 1955 & \begin{tabular}{|l|} 
Los Angeles \\
\end{tabular} \\
\hline N30 & Kilbury House & 1956 & Palos Verdes \\
\hline N31 & Slavin House & 1956 & Santa Barbara \\
\hline $\mathrm{N} 32$ & Clark House & 1957 & Pasádena \\
\hline $\mathrm{N} 33$ & Oxley House & 1958 & La jollia \\
\hline N34 & Ninneman House & 1959 & \begin{tabular}{|l|} 
Claremont \\
Clar
\end{tabular} \\
\hline N35 & Olyer Honse & 1959 & Lone Pine \\
\hline N36 & Singleton $\mathrm{Hous}$ & 1959 & L.os Anzeles \\
\hline N37 & Bond House & 1960 & San Diego \\
\hline N38 & Inadomi Housc & 1960 & Los Angeles \\
\hline N39 & Kambara House & 1960 & Los Angeles \\
\hline $\mathrm{N} 40$ & Pickering House & 1960 & Newport Bexth \\
\hline$\frac{N 41}{N 4}$ & Sale House & $\mid 1960$ & $\frac{\mid}{\text { Los Angeles }}$ \\
\hline $\mathrm{N} 42$ & Cytron House & $\mid 1961$ & Beverly Hills \\
\hline $\mathrm{N} 43$ & Oberholtzer House & 1961 & \begin{tabular}{|l} 
Rolling Hitls \\
\end{tabular} \\
\hline $\mathrm{N} 44$ & Ohara House & 1961 & Los Angeles \\
\hline $\mathrm{N} 45$ & Maslon House & 1962 & Cathedral City \\
\hline $\mathrm{N} 46$ & Taylor House & $\frac{902}{1964}$ & $\begin{array}{l}\text { Glcudale } \\
\end{array}$ \\
\hline
\end{tabular}

あり，外部においては壁，植栽，建物によって分節されたパティオ やヤード，アウトドアリビングといった空間である．また，前面道 路は玄関への主要なアプローチが存在する道路とする。

外部空間の性格の定義に当たっては，個々の空間が単独で性格が 決定されているのではなく，相互の関係のもとに成立していると考 え，連続する内部空間の共用，個人用の性格によって外部空間の性 格を定義することを前提とする。

以上をふまえ，内部空間の性格によって外部空間を定義し，それ ら異なる性格を持った外部空間の構成によって敷地全体を記述する ことにより，敷地と住宅の関係を図式化することを試み，カリフォ ルニアの近代住宅の特徴を明らかにする.

対象作品は, 表 1 に示すシンドラー40件 (S01～S40)，ノイトラ 46件 (N01 N46) の戸建て住宅とし，資料として，シンドラーに関 しては，オリジナル図面を写真により納めたもの ${ }^{29)}$ ，実測調査によ り図面をおこしたもの ${ }^{18)}$ を，ノイトラに関しては作品を年代順に紹 介したもの ${ }^{30)}$ をれぞれ主なものとし，その他の既往の文献 ${ }^{31)}$ と 1994年から1998年の現地調査 ${ }^{32)}$ によって補っている.
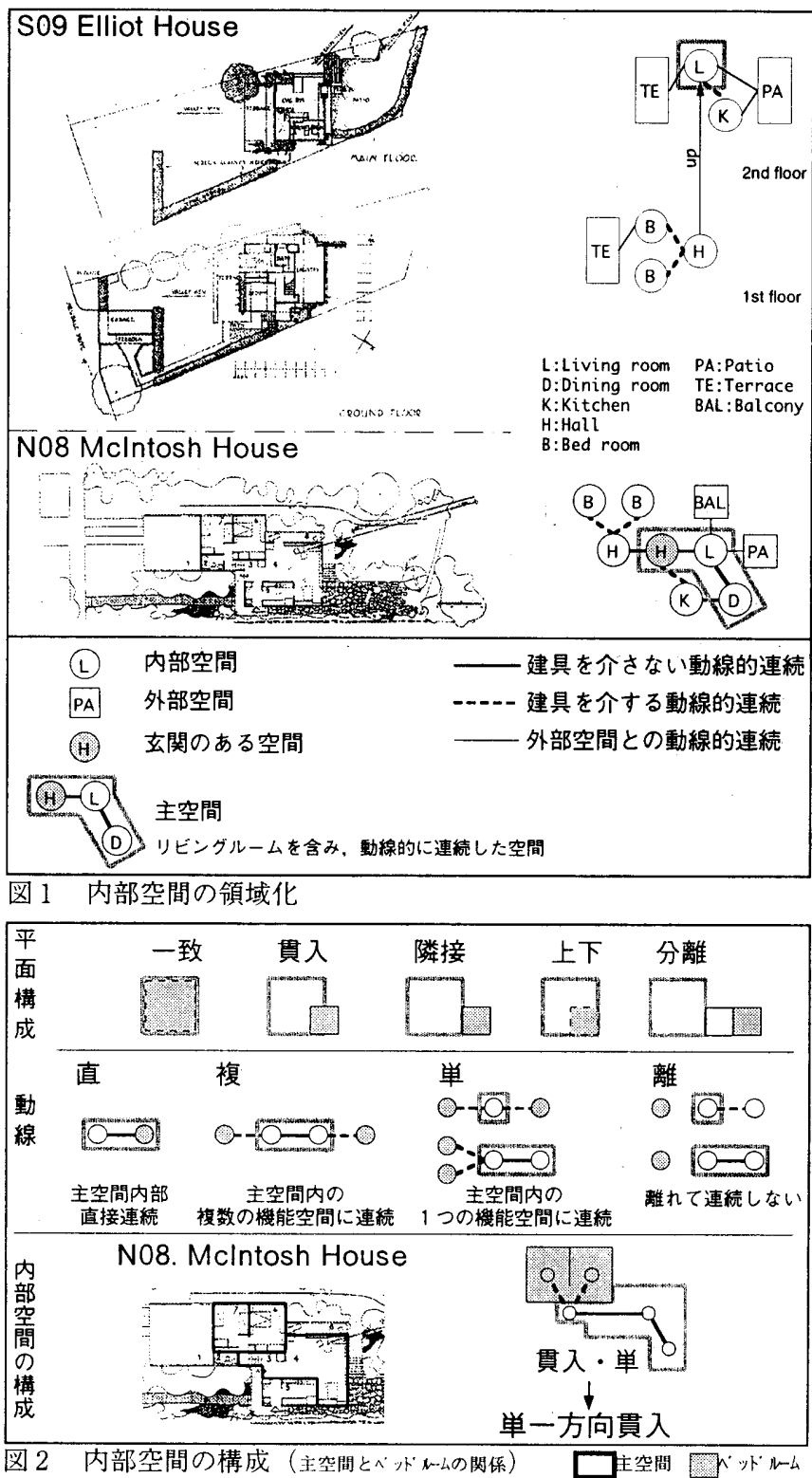
本論では，3章において，住宅内部をリビングルームを含み動線的に連続した主 架間とそれ以外に領域化し, 主空間とベッドルームの空間相互の平面構成, 動線 的関係について分析を行う。そして，二つの関係から共用，個人用の関係による内 部空間の構成を明らかにする。

4 章では，屋内の機能空間が形成するヴォリュームとしての建物，壁や植栽等な どの外部空間を分節する要素を定義する，そして，敷地全体を建物と個々の外部空 間に分割したうえで，それぞれの外部空間を内部空間との関係から性格付けし，内 外空間の総合的な連続について考察する．また，外部空間の性格と建物との相対的 な位置を記述する。

5 章では，内部空間の構成と外部空間の性格を合わせて考えることにより，建物 と外部空間を含めた敷地全体の構成を探り，両者の住宅作品を比較考察することで, カリフォルニアの近代住宅の特徴の一端および両者にみられる手法の差異を示す。

\section{3. 内部空間の領域化}

住宅の内部空間はリビングルームやベッドルームといった異なる機能の集合であ り，それらの空間は建具や壁によって分節されている。ここでは，その分節の度合 いに応じて内部空間を領域化し，個々の空間の性格と合わせて考えることにより対 象作品を分類する。

住宅内部の空間を分節する要素としては，壁，建具が考えられ，特に本研究では， 建具による動線的分節に着目する。ここで，リビングルームを含み，建具を介さず 動線的に連続した機能空間による領域を主空間とする。図 1 は対象を平面の動線的 関係によって樹形図として記述したものである，さらに内部空間における共用，個 人用の関倸を探るため，樹形図をもとに，図 2 のように主空間とベッドルームの関 係を，平面構成と動線の二つの関係によって捉える。平面構成には，二つの空間 が同一の場合（一致），入り組んで隣り合う場合（貫入），単純に直線的に隣り合 う場合（隣接），階を異にする場合（上下），平面的に隣り合わない場合（分離） がある。また，動線の関係には，ベッドルームが，主空間内にあり建具を介さない 直接連続（直），主空間内の複数の機能空間への建具を介した連続（複），主空間 内の単一の機能空間への建具を介した連続（単），主空間とベッドルームが動線的 に離れている場合（離）がある。これら平面構成と動線の関倸をもとに，内部空間 の構成を捉えたものが表 2 であり，以下に各分類の内容を示す.

「一体」は，主空間内にベッドルームとしての機能があるもので，一つの空間で 形成されているものであり個人用の空間が共用の空間に含まれている.

「連続」は主空間とベッドルームが建具では仕切られておらず，部分的に連続し ているものである。

「複数方向」は，複数のベッドルームが主空間の異なる機能空間にそれぞれ隣接 するものであり，「複数方向隣接」，「複数方向貫入」と「複数方向上下」の 3 種 がある，上下の場合，より共有と個人用の区別がなされているといえる，

「単一方向」は，主空間内の特定の機能空間にベッドルームが連続している場合 で，「単一方向隣接」と「単一方向上下，分離」がある。このうち「単一方向上下，分 離」は主空間とベッドルームを上下の階に分けるか，平面的に他の室を挟むことに よって構成的に分離しながら動線的には内部でつながっているものである、

主空間とベッドルームが動線的に離れているものには，建物の内部で，仕切られ， 外部空間を経由することによってのみ移動の可能な「内部分離」，建物自体が分か れている「分棟」がある。

全体として，「単一方向隣接」と「単一方向貫入」が多く，動線が単純化されて いる．シンドラーとノイトラを比較すると，ノイトラの作品が「複数方向隣接」に 多く，シンドラーの作品が「単一方向上下，分離」に多い。このことは基本的に敷地 面積の広さがその可能性を左右する問題であると思われるが，「複数方向隣接」は 異なる方向にベッドルームを設け，それぞれの距離をおき敷地内の位置によって個
表 2 内部空間の構成

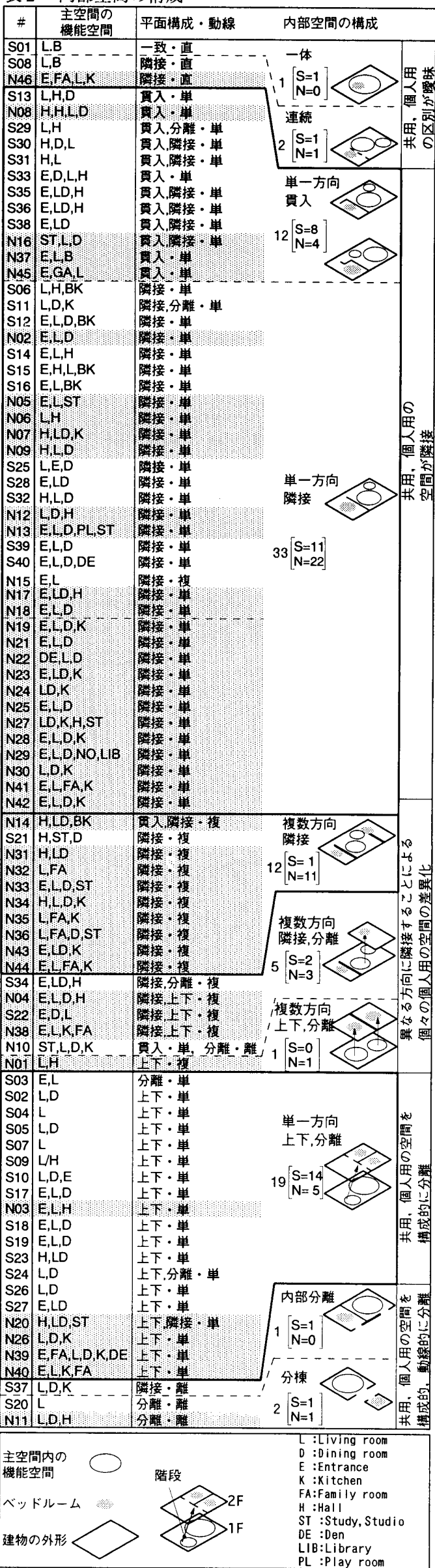


人用空間の差別化を図るものと解釈でき，「単一方向上下,分離」の 中でも S 03，S 19，S 24，S 27は敷地面積が十分あり，この場合にはむ しろ階を異にすることや平面的な構成関係を分離することによって 主空間とベッドルームの性格の違いを明確にし，それと同時に外部 空間を十分に確保するための構成であるとも考えられる。

\section{4. 外部空間の性格と位置}

住宅の外部空間は，建物や壁，植栽によって細分化されており， 本研究ではそれらの性格を内部空間との関係によってとらえる。ま ず，図 3 のように建物と，それと一体となったガレージやテラスな どの外部空間を区別し，つづいて，それらも含めた個々の外部空間 の位置を建物との関係により，図4のように定義する.

表 3 は，3章において明らかにした主空間，ベッドルームの関係 主空間の性格を共用, ベッドルームの性格を個人用とし, 共用, 個 人用の関係によって内部空間に連続する外部空間の性格を分類した ものである．外部空間を性格によって分類すると，共用，個人用そ れぞれの空間への連続の組み合わせから共用，個人用（個単，個棈）， 混用の 3 種類の外部空間の性格が挙げられる。ささらにプールやスリー ピングポーチなどの名称があり，それ自体が特定の機能を示す外部 空間（特），その他の内部空間に連続する外部空間（他），内部空 間に連続しない外部空間（無），駐車スペース（車），玄関へ至る

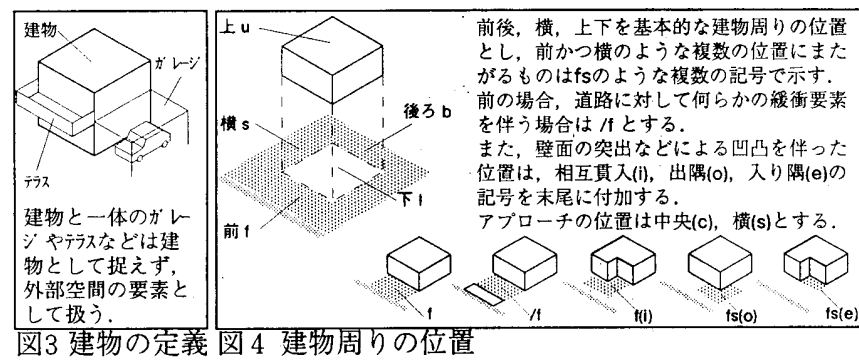

表 3 外部空間の性質

\begin{tabular}{|c|c|c|c|}
\hline 内部の主空間のみに接続 & 共用 & $\begin{array}{l}\text { プールなどの特定の空間 } \\
\text { (名称が特定の機能示すもの) }\end{array}$ & 特 \\
\hline \multirow{3}{*}{$\begin{array}{l}ヘ^{*} \text { ッドームのみに接続 } \\
\text { 单一の個人用空間に連続 } \\
\text { 複数の個人用空間に連続 }\end{array}$} & \multirow{3}{*}{$\begin{array}{l}\text { 個人用 } \\
\text { 個単 } \\
\text { 個裡 }\end{array}$} & その他の機能空間へ連続している & 他 \\
\hline & & どこにも連続していない & 無 \\
\hline & & 駐車ス & 車 \\
\hline 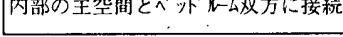 & 混用 & カアブ & $\nabla$ \\
\hline
\end{tabular}

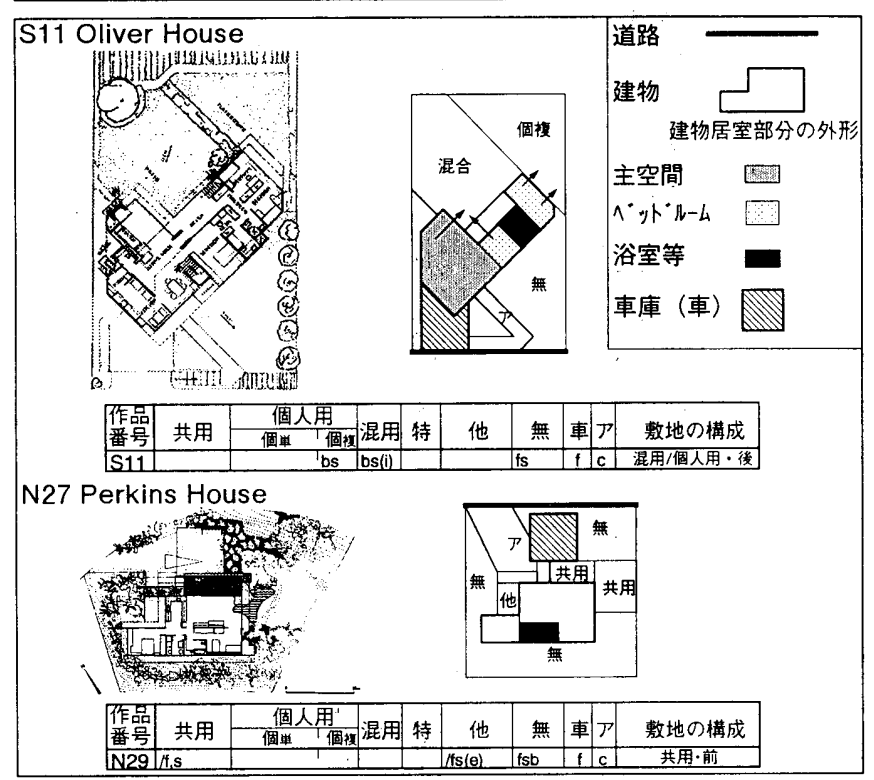

図 5 外部空間の記述
アプローチ（ア）がある. それら個々の外部空間の性格と位置を記 述することにより敷地全体の性格を把握する。

以上をもとに各対象について性格ごとの外部空間の位置を図 5 の ように記述し，特に，共用，個人用，混用の 3 つの性格にもとづき

表 4 外部空間の性格と位置

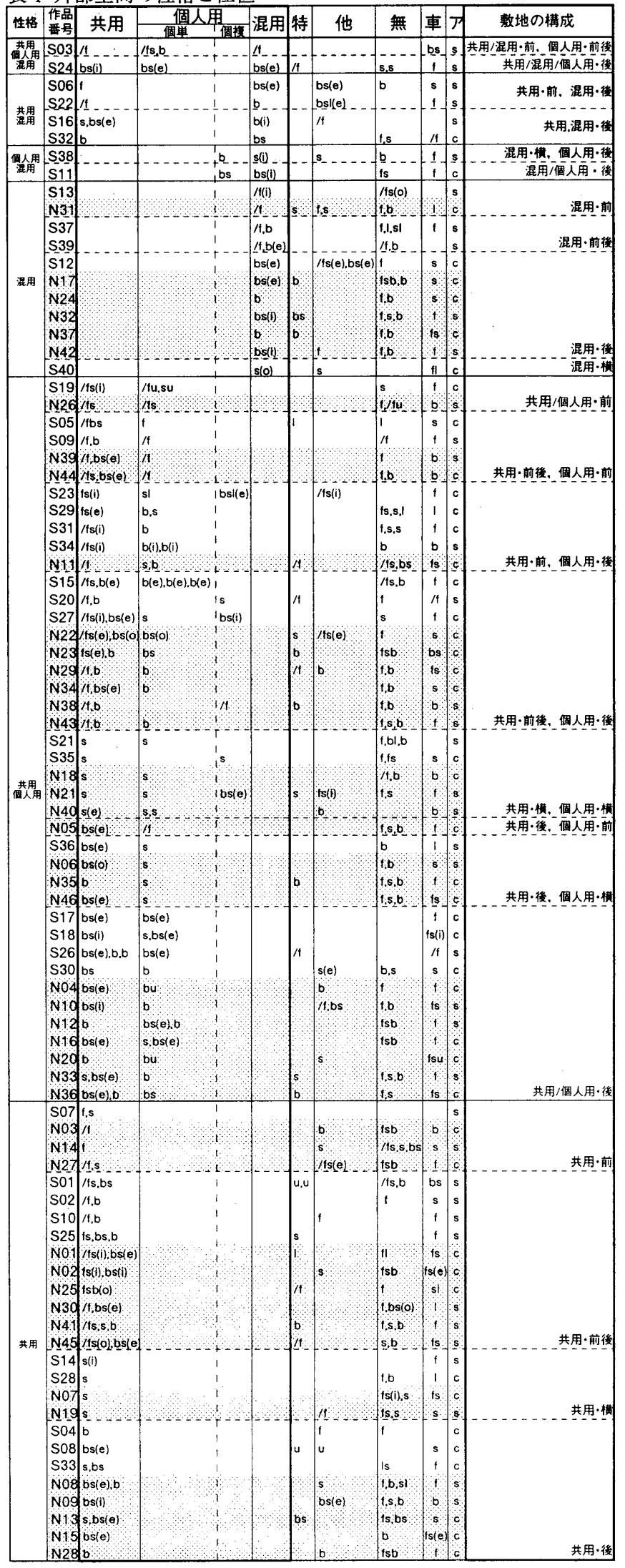


整理したものが表 4 である。 また，共用，個人用，混用のそれぞれの位置を 整理し，敷地の性格として示した。

敷地の構成を性格の有無のみによって捉えると共用，個人用，混用が存在 する場合，共用と混用が存在する場合，個人用と混用が存在する場合，共用 と 個人用が存在する場合，共用のみ存在する場合，によって大きく把握できる. また，特定の外部空間（特）は，シンドラーではスリーピングバスケットや 暖炉を併設したアウトドアリビングであり，ノイトラではプールである場合 が多い．また，駐車スペース（車）は建物の前にあることが多く，前に位置 する外部空間と前面道路の緩衝空間として作用している。

外部空間における性格を，内部空間の延長として考えると，共用の場合は リビングルームを含んだ主空間の延長として，個人用の場合はベッドルーム の延長として，混用の場合は，両者を外部で統合する存在として考えられる. そこで，3章における内部空間の構成と外部空間の性格をあわせて整理し， 図6のように整理すると，6つの典型的な類型が得られた。

(1)は，建物が主空間とベッドルームの二方向に分かれ，対応するように外部 空間も共用，個人用の二つの性格に分かれているものである.

(2)は，複数方向にベッドルームを設け，主空間とベッドルームそれぞれに外 部空間を設けたものであり，共用と個人用の空間ともに独立した内外の関係 がある。

(3)は，(1)の状態を建物の上下に置き換えたものである。

(4)は，内部で隣接している主空間とベッドルームが同一の混用外部空間につ ながり，そこをへて内部空間が連続するものである。(5),6)，主空間のみに 外部空間がつながり，ベッドルームは内部空間のみで成立している。このう ち(6)は上下に共用，個人用の関係があり，共用空間のみ内外の関係が成立す るものである。

表全体を概観すると，ノイトラの作品が典型的な類型に多く有り，特に(1) や(5)のような単一方向隣接に共用と個人用の外部空間や共用の外部空間を組 み合わせた単純な構成に多いのに対して，シンドラーの作品には散らばりが みられる．特に，主空間とベッドルームを外部でつなぐ混用の外部空間があ るものにシンドラーの作品が多く，外部空間が内部空間相互の関倸を活性化 するものと考えることができる.

\section{5. 外部空間の性格と位置による敷地の構成}

4 章において記述した外部空間の性格は，前面道路との関係からその位置 を考え，敷地全体の構成とすることにより，建築家の敷地に対する理解を反 映したものと考えることができる，そこで，外部空間の中でもっとも個人的

\begin{tabular}{|c|c|c|c|c|c|c|}
\hline & \multicolumn{6}{|c|}{ 敷地に存在する外部空間の性格 } \\
\hline & 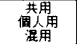 & $\begin{array}{l}\text { 共用 } \\
\text { 混用 }\end{array}$ & \begin{tabular}{|l|} 
佩人用该用 \\
\end{tabular} & 湿用 & $\begin{array}{r}\text { 基用 } \\
\text { 值人用 }\end{array}$ & 共用 \\
\hline 政 & & & & & N46 & S01 S08 \\
\hline 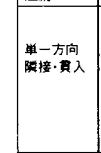 & & $\begin{array}{l}\text { S06 } \\
\text { S32 } \\
\text { S16 }\end{array}$ & $\begin{array}{l}\text { S11 } \\
\text { S38 }\end{array}$ & $\begin{array}{l}\text { S12 S13 S39 } \\
\text { S40 } \\
\text { N17N24N37 } \\
\text { N42 }\end{array}$ & $\begin{array}{r}S 15 \mathrm{~S} 29 \mathrm{~S} 30 \\
\text { S31 S35 S36 } \\
\text { N05N06N12 } \\
\text { N16N18N21 } \\
\text { N22N23N29 } \\
\text { (1) }\end{array}$ & \begin{tabular}{|r|} 
S14 S25 S28 \\
S33 \\
N02N07N08 \\
N09N13N19 \\
N25N27N28 \\
N30N41N45 \\
5
\end{tabular} \\
\hline 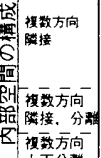 & & & N32 & N31 & $\begin{array}{l}\text { S21 } \\
\text { N33N34N35 } \\
\text { N36N38N43 } \\
\text { N44 } \\
\text { S22 } 534 \\
\text { N04N10 }\end{array}$ & $\mid \begin{array}{l}\mathrm{N} 14 \mathrm{~N} 15 \\
\mathrm{~N} 0 \overline{1}\end{array}$ \\
\hline $\begin{array}{l}\text { 蚌一方向 } \\
\text { 上下分踓 }\end{array}$ & 503524 & & & & $\begin{array}{ll} & \\
\text { S05S17 S18 } \\
\text { S19 S23 S26 } \\
\text { S27 } \\
\text { N4ON20 } \\
\text { N26N39 }\end{array}$ & $\begin{array}{l}\mathrm{S} 02 \mathrm{~S}_{2} \mathrm{~S} 07 \\
\mathrm{~S} 09 \mathrm{~S} 10 \\
\mathrm{~N} 03\end{array}$ \\
\hline 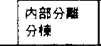 & & & & S37 & $\begin{array}{l}\text { S20 } \\
\text { N11 }\end{array}$ & \\
\hline
\end{tabular}

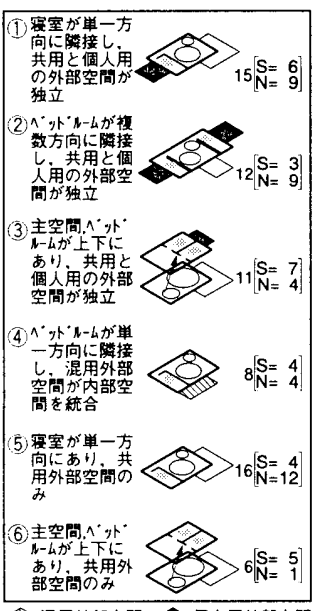

表 5 外部空間の性質と位置による敷地の構成

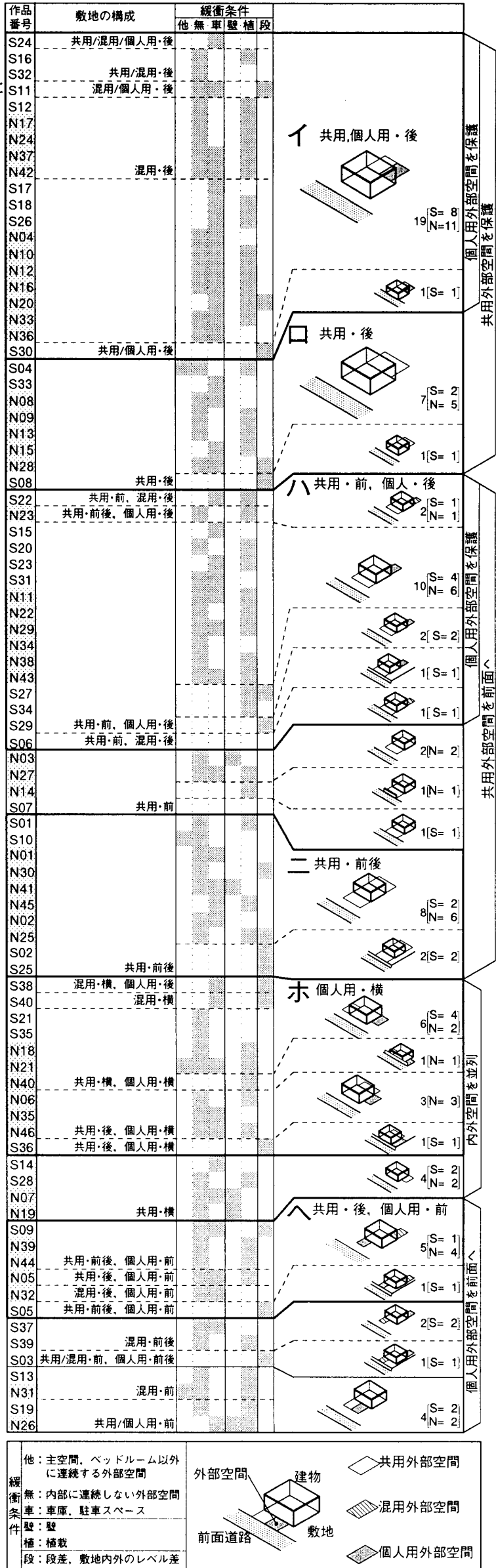


な空間である個人用外部空間を基準に, 共用外部空間, 混用外部空 間の位置も含めて整理し，さらに建物と前面道路の楥衝条件となる 空間や要素を記述し図式化したものが表 5 であり，以下は得られた 類型の特徴である.

イ：「共用/個人用・後」は，共用外部空間も個人用外部空間もどちら も建物に対して敷地の後ろに位置し, 前面道路に対しては閉じた構 成である。これによってどちらの外部空間も公共空間から保護され ている。

ロ：「共用・後」は, 共用外部空間が敷地の後ろに位置し, 前面道路 に対しては，その他の外部空間が面するか，建物が直接対邿してい る.

イ、口は共に外部の居住空間が建物の後ろに位置する場合であるが, 建物のが直接道路に対畤する場合は少なく何らかの緩衝条件を伴っ ている。

八：「共用・前，個人用・後」は，共用の外部空間が敷地の前あるいは 前後に位置し, 個人用の外部空間が後に位置し後方に開くものであ る. 個人用の空間を建物の後ろに保護しようという意図が伺える. 前面道路に対して共用の外部空間が対峙することは少なく, 緩衝条 件を伴っている.

二：「共用・前後，個人用・無」は，共用の外部空間が敷地前面に位置 し，前面道路に対峙しているが，さらに建物の後ろにも共用の外部 空間がある場合である。この場合，何らかの緩衝条件が前に位置す る共用の外部空間と道路の間にある場合が多い.

木：「個人用・横」は，個人用外部空間が建物の横に位置し，前面道 路との関係上, 内外の個人用空間が等価にあるものである。これを 基本に共用外部空間が横に位置するもの，後ろに位置するものがあ る.

へ：「共用・後，個人用・前」は，個人用外部空間が敷地の前に位置し， 共用外部空間が後ろに位置するもので, 共用の空間を建物の後方で 保護している。

これらの類型の内, 共用, 混用の外部空間が建物の後ろにある場 合は，イ、ロ，ハの一部、二, ホの一部、へなどの52例と多く, 前 面道路から共用の外部空間を保護し, 敷地の後方へ住宅を開こうと していることがわかる。これらの多くが, 前面道路と前に位置する 外部空間の間に緩衝条件となる外部空間や植栽, 壁, 段差などを伴っ て扔り，このことから，前面道路に対して，景観緩衝空間としての 外部空間 $\rightarrow$ 建物 $\rightarrow$ 共用の外部空間という図式が多く成り立っている といえる。また，個人用もしくは混用の外部空間が，建物の後ろに ある場合が37例，建物の前にある場合が13例. 横にある場合が11例， 無い場合が26例と，後ろにある場合が相対的に多いが，無い場合も 多く, 内部のベッドルームとの関係から考えると, ベッドルームを 後方に開放するか内部空間のみで完結する場合が多いと言える。

類型間の関係を探ると，イ，口は外部空間の保護という点で，八， 二は共用外部空間を前面道路と対時させるという点で，イ，八は個 人用外部空間を保護するという点でそれぞれ類似している。ロ，二 は共用外部空間の位置において異なるが，個人用外部空間の無い点 で個人用空間を内部のみに限定し保護しているといえる。

全体的に，共用の外部空間を後ろに保護する傾向にあり，個人用 外部空間が無い場合はベッドルーム自体を建物の中で完結させ，外 部空間との関係を絶っており, 個人用の空間を保護しょうという意
図が伺える。

\section{6. 結論}

本研究では, シンドラーとノイトラの住宅作品を対象に内部にお ける機能空間の動線的関係と，内部空間との関係にもとづく外部空 間の性格について考察し，内外を総合的にみた共用，個人用による 関係と, 前面道路との関係による敷地の構成について考察を行った.

結論を要約すると以下のようになる。

・住宅の内部空間について，共用と個人用の空間の差異を記述する 手段として、リビングルームを含み動線的に連続した主空間を定義 し, ベッドルームとの平面構成, 動線関係から内部空間の構成を記 述した，対象の特徵として，単一方向の隣接，貫入が多く，内部の 動線は単純化されていることが明らかになった．また，上下に共用 と個人用を区別する構成にシンドラーの作品が，平面的に複数方向 へ共用，個人用を区別する構成にノイトラの作品が多いという独自 性が見られた。これらの独自性は，敷地の面積や形状といった条件 に関係するとは考えられるが，それぞれ，内部の共用空間と個人用 空間の差異, 個人用空間相互の差異を明確化する構成として解釈で きる。

・外部空間の性格を把握する手段として，細分化された外部空間と 内部空間との関係に着目し，共用，個人用を基本に複数の外部空間 の性格を定義し，前面道路との関係により記述を抽なった。また， 外部空間を共用，個人用，混用の差異によって性格付けし，それに よる分類と内部空間の分類をあわせ，外部空間も含めた住宅全体の 共用，個人用による総合的関倸を把握した，対象にみる共用，個人 用による内外空間の総合的関係は，内部空間の単純な隣接とそれに 応じた外部㞬間という場合と，内部空間の単純な隣接，共用の外部 空間のみの 2 種が特に多く，シンドラーが典型的な類型内に必ずし も該当しないのに対し，ノイトラの多くはそれらに該当している. ・前面道路との関係から個々の外部空間の性格と位置を記述し，敷 地全体の性格を探る方法を提示した，対象の多くは，敷地の後ろに 共用,個人用の双方もしくは共用の外部空間があり，内部空間との関 係を敷地の後方にとる傾向にある．また，前面に個人用外部空間を とる場合も，後方にも同じょうに個人用外部空間を配置する傾向に ある，基本的な図式は，前面道路 $\rightarrow$ 景観, 緩衝空間としての外部空間 $\rightarrow$ 建物 $\rightarrow$ 共用の外部空間である。

本研究においては，住宅の外部空間に反映された建築家の敷地に 対する理解を前面道路や内部空間との関倸によって明らかにしたが， 今後は対象を他の地域の住宅に拡充することによって, 複数の地域 の住宅群を相対的に論じることが課題である．また，分析範囲を隣 地や景観などの周辺環境へとひろげることで，住宅の建つ地域の状 況をより反映できる可能性がある。

評:

1) 那須 琹，北原和俊，大島ヶン正，八木幸二「『ケース・スタディ・ハウス・フログラ

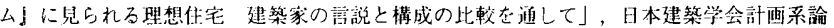
文集第508号，249-255，1998年6月

ケース・スタディー・ハッスを建築装による言説と住宅の情成面から分析，比較するこ

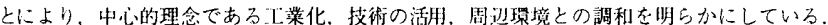

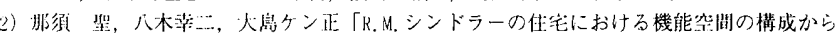

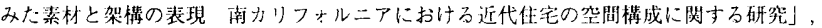
日本建筑学会計画系論文集筑517号，313-319，1999年3月

シンドラーの住宅作品について, 装材・架棈表現との関連から，平面部画に内在する内 外空閂及び隣接す万機能些閂の関進を四式化している。 
3）那須 聖, 村田 涼, 加用雅信, 八木幸二「内外空間の配置・配列構成にみる近代住宅 の建物と敷地の関係に関する研究 南カリフォルニアにおけるR.M.シンドラーとR. J.ノイ トラの戸建て住宅作品の比較を通して」，日本建築学会計面系諭文集，藉查中 上記諭文に関連して, 村田涼, 那須聖, 根岸揵一, 八木幸二「R.M.シンドラーとR. J.ノイ トラの住宅作品における内外空間の配置·配列構成」, 日本建築学会大会学術講演梗概集 F2，505-506，1999年9月がある。

4）村田 涼, 八木幸二, 那須 聖「R.M.シンドラーの住宅における空間の隣接関倸による 屋外の居室性」，日本建築学会大会学術講演梗概集E2，65-66，1997年9月

5）那須聖，八木幸二, 金田建「アーヴイン・ギルの住宅における内外空間の機能的分割と 統合」，日本建築学会大会学術講演梗概集F 2，503-504，1998年9月

註3）,5）においては，それぞれの住宅作品を对象に，段差や植栽によって分節された外 部空䦭の性格を内部の居室との関連により明らかにしている.

6）加用雅信，那須聖，八木幸二「R，ノイトラの住宅作品に見られるリビングを中心とし た内外のつながりから見た空間構成」, 日本建築学会大会学術講演梗概集 F 2,509-510, 1998年9月

特にリビングを中心とした空間の構成に着目し，開口部，架構，アプローチ，瞵接する 外部空間の構成を類型化している。

7）ルドルフ・ミヒヤエル・シンドラー(Rudolph Michael Schindler 1887-1953)はウィーン に生まれ、オットー・ワーグナーのもとで建等を学か，1914年アメリカに渡り，シカゴのオ ッテンハイマー・スターン・アンド・ライカールト事䅂所においてドラフトマンをした後, 1917年よりシカゴ及びタリアセンにてフランク．ロイド・ライトのもとで働くが，1920年に ライトのバーンズドール邸の設計のためにロサンジェルスに移り住み，その後，1923年ま でライト事務所に所属．ロサンジェルスにおいてシンドラーはフィリップ・ロベル博士の 健康理論の影繁から屋外の住環境に興味を示しており，雑誌に幾つかの寄稿がある。

8)リチャード・ジョセフ・ノイトラ(Richard Josef Neutra 1892-1970)はウィーンに生ま れ、ワグナーのもとで建筑を学び、ロースの事務所で働く。この頃にシンドラーと出会っ て㧍り，两者は作品集でライトの作品を知ることになる。ベルリンでE.メンデルゾーンと 協同した後，1923年に渡米，ニューヨークへ移住する。 その後ライトの下で儌き，1925年 にロサンジェルスで事移所を開設する。

9) McCoy, Esther "Vienna to Los Angeles : Two Journeys",Arts + Architecture Press, 1979 10) Gebhard,David "Schindler", Viking Press, 1971

訳書に末包伸吾「ルドルフ・シンドラーカリフォルニアのモダンリビング」鹿島出版全

，1999年5月がある。

11) McCoy , Esther "Five California Architects", Hennessey \& Ingalls, 1987

オリジナルは1960年にREINHOLD BOOK CORPORATIONより発行.

12) Sarnitz, August, "R.M.Schindler Architect 1887-1953", Rizzori, 1988

13) "R.M.Schindler 10 Houses",2G No.7, Editorial Gustavo Gill,SA ,1998

シンドラーの住宅作品を10作取り上げ，写真と図面付きで詳細に解説している。

14) Hines, Thomas S. "RICHARD NEUTRA AND THE SEARCH FOR MODERN

ARCHITECTURE", University of California Press, 1982

15) Boesiger, Willy "Richard Neutra 1923-50,1950-60,1961-66 Buildings and

Projects", Verlagfur Architektur, 1951,1959,1966

16）国際建築家協会編「リチャート・ノイトラ」，美術出版社，1953

17) "GA No. 8", A.D. A. Edita Tokyo

18）バス・クレモス，ステフアノ・ボリゾイデス「R，M.シンドラー特集ーR，M.シン ドラーの住宅 5 題」A+U 1975年11月に納められた实測図面

19) Ford,Edward R. "The Details of Modern Architecture", MIT Press,1990(vol.1),1996(vol.2) 訳に筆者らの「巨匠たちのディテール」1，2巻，丸善出版，1999年3月

vol.1においてシンドラーの作品とノイトラの初期の作品, vol.2においてノイトラの作品 が取り上げられ，その架構形式が解き明かされている。

20) Edited by Lionel March and Judith Shine "R.M.Schindler Composition and Construction" Academy Edition, 1993

21）末包伸吾「シンドラーのウィーン美術アカデミー在籍中の建築論に見るワグナーの影 闇について」日本建築学会大会学術講演梗概集, 499-500,1995年8月

22）末包伸吾「ルドルフ・シンドラーの住宅建筑における空間構成材とモデュールによる

空間構成法了日本建筑学会計画系諭文集No.494,261-268, 1997年4月

23）来包伸吾「部屋の構成とシークエンス計画にみるルドルフ・シンドラーの等間構成法

」日本建筑学会計酒系論文集No497，221-227，1997年7月

24）弓立基紀，末包伸吾，系嶺円路「リチャード・ノイトラの住宅作品における空間構成

材と配置・平面計画に関する考察」日本建築学会近畿支部研究報告集, 981-9841998年

25）糸嶺冈路，末包伸吾「リチャード・八イトラの代宅作品における平面・立体構成とモ

デュールに関する考察」日本建築学会近畿支部研究報告集, $985-988,1998$ 年:

26）長谷川洋，王置伸伍「敷地条件加らみた新智・石建て住宅平面の典型像とその構成原

理」日本建築学会計画系諭文集 第483号，189-198，1996年5月

27)川北健雄「1990年に発表された国内の住宅作品における外部と内部の配㯰構成に関寸る 研究」日本建笑学会阡画系論文集 第497号，103-110，1997年7月

28) Schindler,Rudolph M., "Care of the body" edited by Philip Lovell, LA TIMES, 詳12に掍 载. Neutra,Richard J., 'Article:" House and Home : a manual and text book of practical house planning"by Grey, Greta, J.B. LIPPINCOTT COMPANY,Third Edition, Revised, 1935

29) Gebhard, David, "The Architectural Drawings of R.M.Schindier", 1993

30）洁の14)，15)，16) 中の国而と写真

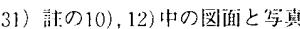

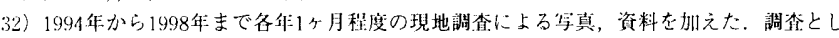

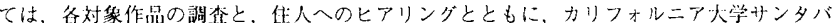
ーバラ校における圈砶㖫查を行っている。

参考文献

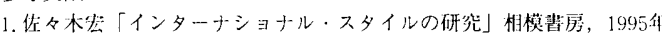

2.H.R.ヒッチコック，P.ジョンソン，武沢秀一訳「インターナショナル・スタイル」麇島 出版会, 1978年

3.ロバート・スウィニー「真性のカリフォルニア建築」GA Houses26, 1989年7月

4. Gebhard, David, "Schindler", Viking Press, 1971

5. Drexler, Arthur, "The architecture of Richard Neutra : from international style to California modern", MoMA, 1982

6. "BLUEPRINTS FOR MODERN LIVING History and Legacy of the Case Study Houses" edited by Elizabeth A.T.Smith. The Museum of Contemporary Art, Los Angeles, 1989 1998年にThe MIT Pressより再版

(1999年7月10日原稿受理，1999年 9 月21日採用決定) 